\title{
Influence of Continuous Organic Amendments on Growth and Productivity of Red Pepper and Soil Properties
}

\author{
Youngho Seo*, Sewon Kim, Seungchul Choi, Byeongchan Jeong, and Yeong-Sang Jung ${ }^{1}$ \\ Gangwon Agricultural Research \& Extension Services, Chuncheon 200-150, Korea \\ ${ }^{1}$ Kangwon National University. Chuncheon 200-701, Korea
}

\begin{abstract}
Organic farming has rapidly increased in Gangwon province, but there is a concem about nutrient accumulation and nutrient imbalance in the soil of organic farming. This study was conducted to investigate the impact of continuous application of organic amendments on growth and yield of red pepper and soil characteristics compared with chemical fertilizers application for four years. Treatments of organic amendments including oil cake, rice straw compost, amino acid compost, rice bran compost, and mushroom media (spent substrate) compost resulted in comparable growth and yield of pepper to chemical fertilizers. Organic amendments improved soil physical and chemical characteristics. Especially, rice bran compost and oil cake significantly increased soil organic matter compared with chemical fertilizer application and mushroom media compost and rice straw compost significantly improved soil aggregate stability. On the other hand, available phosphate level in the soil amended with rice bran compost or mushroom media compost was relatively high compared with the other treatments due to relatively high phosphate levels in the composts. It is not easy to adjust nutrient composition in the organic materials. Therefore, the results obtained from the study imply that nutrient imbalance needs to be carefully considered in organic farming without use of chemical fertilizers.
\end{abstract}

Key words: Organic farming, Soil properties, Nutrient balance, Red pepper

\section{Introduction}

Organic farming has rapidly increased in response to consumer's preference to safe food, farmer's desire to live in a clean environment, and government's policy to reduce fertilizers use. Certified number of farms, area, and products for organic farming increased from 442, $450 \mathrm{ha}$, and $10,672 \mathrm{Mg}$ in 2001 to $10,790,15,517$ ha, and 122,243 Mg in 2010, respectively (National Agricultural Products Quality Management Service, 2012). In Gangwon province, the number of farms, area, and products increased from 62, 66 ha, and 1,391 $\mathrm{Mg}$ in 2001 to $1,021,1,636 \mathrm{ha}$, and 14,385 Mg in 2010 , respectively.

There is a concern, however, about nutrient accumulation and nutrient imbalance in the soil of organic farming and nitrate contamination to ground water due to over-application of livestock compost and organic amendments including oil cake. Lee et al. (2006)

\footnotetext{
Received : January 10. 2012 Accepted : January 26. 2012

*Corresponding author : Phone: +82332486096

E-mail: seoysh@korea.kr
}

reported that organic farmers generally applied greater amounts of organic amendments including livestock compost than recommended level. Nitrate level in surface soils of organic Chinese cabbage fields was 3.6 times higher than that of conventional farming and 4.7 times for sub-soils (Sohn et al., 1996). Phosphate and electrical conductivity also showed similar trend. Sohn and Han (2000) reported that nitrate level of organic farming soils in Paldang region was four to seven times greater than conventional farming soils nearby, and two times for available phosphate. Cho et al. (2009) also reported that 1.4 times phosphate and 1.5 times potassium for organic farming upland compared with conventional one. In addition, livestock compost has been commonly used in organic farming (Lee et al., 2006). Recently, several researches showed residual veterinary antibiotics in livestock feces and urines (Seo et al., 2007a). Therefore, we need to investigate more organic amendments than livestock compost for organic farming.

The objective of the study was to investigate the influence of continuous application of organic amendments 
on growth and yield of red pepper and soil characteristics compared with chemical fertilizers application.

\section{Materials and Methods}

A four-year experiment was performed at the Gangwon Agricultural Research and Extension Services greenhouse and field in Chuncheon from 2007 to 2010. The soil in the greenhouse and the field is classified to Gyuam silty loam (coarse silty, mixed, nonacid, mesic Aquic Fluventic Eutrochrepts) and the selected chemical properties of the soils are shown in Table 1. Red pepper (Capsicum annuum) was cultivated with organic amendments including oil cake, rice straw compost, amino acid compost, rice bran compost, and mushroom media (spent substrate) compost before transplanting of red pepper seedlings. Chemical composition of the organic amendments on a fresh weight basis is shown in Table 2.

The application rates of organic amendments were determined based on recommended nitrogen fertilization rate after soil testing and nitrogen content of the organic amendments. As a result, less or excess amounts of phosphate and potassium was applied depending on relative nutrient composition of the organic amendments. For instance, phosphate was over-applied for rice bran compost and mushroom media compost and potassium was less-applied for oil cake and rice bran compost compared to recommended fertilization based on soil testing.
The treatments were arranged in a randomized block design with three replicates. All statistical analyses were performed with the SAS (ver. 9.2, SAS, Cary, NC) program. An alpha value of 0.05 was chosen to indicate statistical significance.

The surface soils collected at the $15-\mathrm{cm}$ depth from each plot were air-dried, passed through a $2 \mathrm{~mm}$ sieve, and used to determine soil chemical properties including soil $\mathrm{pH}$, electrical conductivity (EC), soil organic matter, available phosphate, and exchangeable cations by soil analysis method recommended by National Institute of Agricultural Science and Technology (2000). Briefly, soil $\mathrm{pH}$ and $\mathrm{EC}$ were measured after mixing soil with $\mathrm{H}_{2} \mathrm{O}$ at a ratio of 1:5. Soil organic matter and available phosphate were determined by Tyurin and Lancaster method, respectively. Exchangeable cations such as potassium, calcium, and magnesium were analyzed by extracting them with $1 \mathrm{~N}$ ammonium acetate $(\mathrm{pH} 7)$. Amounts of exchangeable cations were determined by inductively coupled plasma spectrophotometer (ICP, GBC Integra XMP, GBC Scientific Equipment Pty Ltd, Victoria, Australia).

Soil bulk density and aggregate stability were measured to determine the soil physical characteristics. Core cylinders with a size of $100 \mathrm{~cm}^{3}$ were pressed to the surface soil and the soil in the core cylinders was dried in the oven set at $105^{\circ} \mathrm{C}$. The bulk density was calculated by weight of oven-dry soil in the core cylinders divided by bulk volume, $100 \mathrm{~cm}^{3}$. For aggregate stability determination, $4 \mathrm{~g}$ of 1 - to $2-\mathrm{mm}$ air-dried soil

Table 1. Selected soil chemical characteristics of the greenhouse and the field used in the study.

\begin{tabular}{lccccccc}
\hline \hline \multirow{2}{*}{ Site } & $\mathrm{pH}$ & Electrical conductivity & Organic matter & \multirow{2}{*}{ Avail. $\mathrm{P}_{2} \mathrm{O}_{5}$} & \multicolumn{3}{c}{ Exch. Cation } \\
\cline { 6 - 8 } & $\mathrm{H}_{2} \mathrm{O},(1: 5)$ & $\mathrm{dS} \mathrm{m}^{-1}$ & $\mathrm{~g} \mathrm{~kg}^{-1}$ & $\mathrm{mg} \mathrm{kg}^{-1}$ & $\mathrm{Ca}$ & $\mathrm{K}$ \\
Greenhouse & 6.3 & 1.3 & 18 & 489 & 6.0 & 0.55 & 2.0 \\
Field & 6.3 & 0.11 & 15 & 456 & 4.3 & 0.51 & 1.3 \\
\hline
\end{tabular}

Table 2. Chemical composition of the organic amendments used in the study.

\begin{tabular}{|c|c|c|c|c|c|c|}
\hline Organic amendment & Organic matter & $\mathrm{T}-\mathrm{N}$ & $\mathrm{P}_{2} \mathrm{O}_{5}$ & $\mathrm{~K}_{2} \mathrm{O}$ & $\mathrm{CaO}$ & $\mathrm{MgO}$ \\
\hline & \multicolumn{6}{|c|}{ - } \\
\hline Rice straw compost & 180 & 7 & 2.0 & 6.5 & 6.6 & 2.9 \\
\hline Rice bran compost & 477 & 19 & 14.0 & 6.3 & 11.2 & 27.6 \\
\hline Mushroom media compost & 297 & 14 & 9.8 & 7.8 & 5.1 & 3.5 \\
\hline Oil cake & 754 & 47 & 21.4 & 11.1 & 5.9 & 6.0 \\
\hline Amino acid compost & 246 & 52 & 5.6 & 25.1 & 21.9 & 13.2 \\
\hline
\end{tabular}


aggregates was evenly spread over the $750 \mu \mathrm{m}$ sieve. The sieve with aggregate sample was placed in the bucket filled with water and moved up and down in the water at the rate of about 34 times per minute for $3 \mathrm{~min}$. The weight of soil in the bucket was determined after drying at $105^{\circ} \mathrm{C}$. Water aggregate stability was calculated by weight of aggregate after dispersing in the water divided by weight of aggregate sample, $4 \mathrm{~g}$.

\section{Results and Discussion}

Leaf greenness of red pepper for the organic amendments was comparable to that for chemical fertilizer in the greenhouse, while low leaf greenness for mushroom media compost in the field (Fig. 1). Decomposition of mushroom media (spent substrate) compost seemed to be relatively slow due to high content of lignin, $60 \%$. Productivity of red pepper for the organic amendments was also comparable to that for chemical fertilizer in the greenhouse, while low yield for mushroom media compost in the field (Fig. 2). The mushroom media compost may improve soil physical properties rather than supply sufficient nutrients to red pepper. Buckerfield and Webster (2002) reported soil physical improvement, soil biological property improvement, and soil moisture conservation effect of mushroom media compost. Therefore, amendment with mushroom media compost is thought to be proper under a greenhouse condition having sufficient plant nutrients including nitrate, phosphate, and potassium rather than open field with relatively low soil fertility.

Application of organic amendments resulted in increase in soil $\mathrm{pH}$ and organic matter (Table 3, 4). In terms of increase in soil organic matter, rice bran compost and oil cake were more effective than the other organic materials. Kim et al. (2004) reported that soil organic matter enhancement effect of organic amendments was in the order of oil cake $>$ pig manure $>$ compost, green manure, rice straw $>$ hairy vetch. Levels of soil available phosphate for rice bran compost and mushroom media compost treatments were relatively high compared with the other treatments possibly due to high ratio of phosphorus to nitrogen
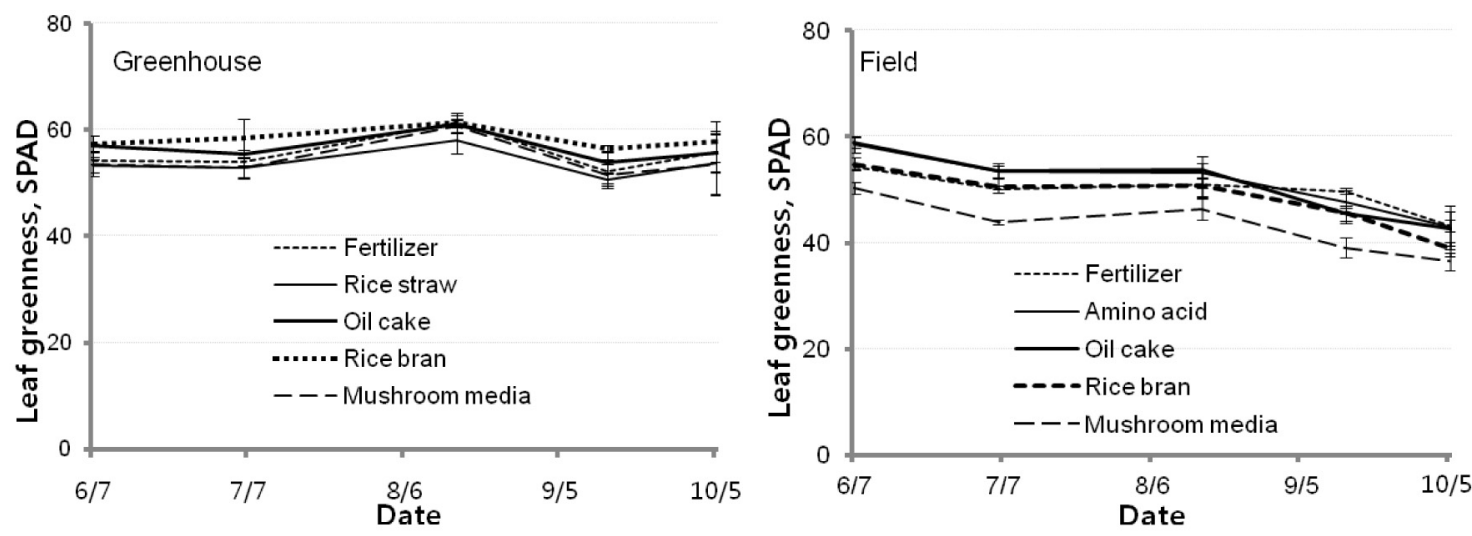

Fig. 1. Leaf greenness of red pepper in greenhouse (left) and field (right). Emor bars indicate \pm 1 standard deviation.
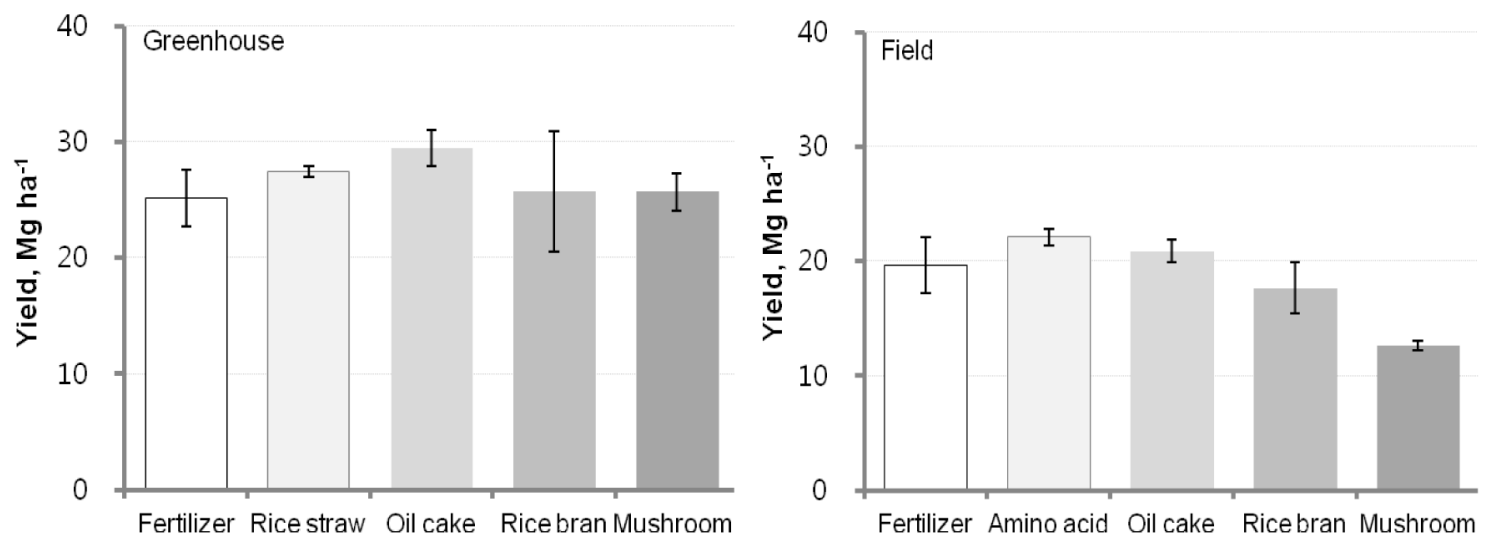

Fig. 2. Yield of red pepper in greenhouse (left) and field (right). Emor bars indicate \pm 1 standard deviation. 
for the composts. Reddy (1999) concluded that repeated application of organic materials with high contents of phosphate could accumulate soil phosphate up to $1,000 \mathrm{mg} \mathrm{kg}^{-1}$. In addition, exchangeable potassium levels for oil cake and rice bran compost treatments were low compared with the other treatments possibly due to low ratio of potassium to nitrogen for the composts. It is difficult to adjust nutrient composition in the organic resources to recommended fertilization. Therefore, nutrient imbalance needs to be carefully considered in organic farming.

Soil physical properties including bulk density and water-resistant aggregate were improved by applying organic amendments compared with those for chemical fertilizer (Table 5). For soil bulk density, organic amendments resulted in significant decrease compared with chemical fertilizer application in greenhouse, while no significant difference among treatments in field. Deterioration of physical characteristics is one of the major problems in greenhouse soils, and many studies have been conducted to improve the soil physical properties (Kim et al., 2001; Seo et al., 2007b). Seo et al. (2007b) suggested that application of organic materials such as rice straw and woodchip

Table 3. Soil chemical properties in the greenhouse after harvesting red pepper.

\begin{tabular}{lccccccc}
\hline \hline \multirow{2}{*}{ Treatment } & $\mathrm{pH}^{\dagger}$ & $\mathrm{EC}$ & Organic matter & Avail. $\mathrm{P}_{2} \mathrm{O}_{5}$ & \multicolumn{3}{c}{ Exch. Cation } \\
\cline { 5 - 8 } & $\mathrm{H}_{2} \mathrm{O},(1: 5)$ & $\mathrm{dS} \mathrm{m}^{-1}$ & $\mathrm{~g} \mathrm{~kg}^{-1}$ & $\mathrm{mg} \mathrm{kg}^{-1}$ & - -------- $\mathrm{cmol}_{\mathrm{c}} \mathrm{kg}^{-1}$ & $\mathrm{Mg}$ \\
Chemical Fertilizer & $6.3 \mathrm{bc}$ & $2.1 \mathrm{a}$ & $18 \mathrm{c}$ & $504 \mathrm{~b}$ & $6.7 \mathrm{a}$ & $0.43 \mathrm{~b}$ & $2.0 \mathrm{a}$ \\
Rice straw compost & $6.7 \mathrm{a}$ & $1.9 \mathrm{a}$ & $19 \mathrm{bc}$ & $572 \mathrm{ab}$ & $6.8 \mathrm{a}$ & $0.76 \mathrm{a}$ & $2.2 \mathrm{a}$ \\
Rice bran compost & $6.4 \mathrm{bc}$ & $2.2 \mathrm{a}$ & $20 \mathrm{ab}$ & $622 \mathrm{a}$ & $6.5 \mathrm{a}$ & $0.42 \mathrm{~b}$ & $2.3 \mathrm{a}$ \\
Mushroom media compost & $6.6 \mathrm{ab}$ & $1.9 \mathrm{a}$ & $20 \mathrm{a}$ & $602 \mathrm{a}$ & $7.0 \mathrm{a}$ & $0.80 \mathrm{a}$ & $2.4 \mathrm{a}$ \\
Oil cake & $6.2 \mathrm{c}$ & $2.1 \mathrm{a}$ & $20 \mathrm{ab}$ & $516 \mathrm{~b}$ & $6.2 \mathrm{a}$ & $0.25 \mathrm{c}$ & $1.9 \mathrm{a}$ \\
\hline
\end{tabular}

${ }^{\dagger}$ Treatments with same letter in each column are not significantly different at the 0.05 probability level.

Table 4. Soil chemical properties in the field after harvesting red pepper.

\begin{tabular}{lccccccc}
\hline \hline \multirow{2}{*}{ Treatment } & $\mathrm{pH}^{\dagger}$ & $\mathrm{EC}$ & Organic matter & Avail. $\mathrm{P}_{2} \mathrm{O}_{5}$ & \multicolumn{3}{c}{ Exch. Cation } \\
\cline { 6 - 8 } & $\mathrm{H}_{2} \mathrm{O},(1: 5)$ & $\mathrm{dS} \mathrm{m}$ & $\mathrm{g} \mathrm{kg}^{-1}$ & $\mathrm{mg} \mathrm{kg} \mathrm{m}^{-1}$ & $-\mathrm{Ca}^{-1}$ & $\mathrm{Mg}$ \\
Chemical Fertilizer & $6.2 \mathrm{c}$ & $0.29 \mathrm{a}$ & $15 \mathrm{c}$ & $503 \mathrm{~b}$ & $4.6 \mathrm{~b}$ & $0.67 \mathrm{a}$ & $1.1 \mathrm{a}$ \\
Amino acid compost & $6.1 \mathrm{c}$ & $0.22 \mathrm{a}$ & $15 \mathrm{c}$ & $496 \mathrm{~b}$ & $6.6 \mathrm{a}$ & $0.49 \mathrm{~b}$ & $1.5 \mathrm{a}$ \\
Rice bran compost & $6.8 \mathrm{a}$ & $0.14 \mathrm{~b}$ & $17 \mathrm{a}$ & $620 \mathrm{a}$ & $4.7 \mathrm{~b}$ & $0.33 \mathrm{c}$ & $1.2 \mathrm{a}$ \\
Mushroom media compost & $6.8 \mathrm{a}$ & $0.10 \mathrm{~b}$ & $16 \mathrm{~b}$ & $623 \mathrm{a}$ & $5.0 \mathrm{~b}$ & $0.58 \mathrm{a}$ & $1.5 \mathrm{a}$ \\
Oil cake & $6.3 \mathrm{~b}$ & $0.13 \mathrm{~b}$ & $16 \mathrm{ab}$ & $492 \mathrm{~b}$ & $5.1 \mathrm{~b}$ & $0.25 \mathrm{c}$ & $1.5 \mathrm{a}$ \\
\hline
\end{tabular}

${ }^{\dagger}$ Treatments with same letter in each column are not significantly different at the 0.05 probability level.

Table 5. Soil physical properties after harvesting red pepper.

\begin{tabular}{|c|c|c|c|c|}
\hline \multirow{2}{*}{ Treatment } & \multicolumn{2}{|c|}{ Bulk density $^{\dagger}$} & \multicolumn{2}{|c|}{ Aggregate } \\
\hline & Greenhouse & Field & Greenhouse & Field \\
\hline & ----------------- & - & - & (n-- \\
\hline Chemical Fertilizer & $1.12 b$ & $1.03 \mathrm{a}$ & $34.5 \mathrm{a}$ & $41.6 \mathrm{a}$ \\
\hline Rice straw compost & $1.08 \mathrm{a}$ & $1.03 \mathrm{a}$ & $39.1 b$ & $54.0 \mathrm{~b}$ \\
\hline Rice bran compost & $1.08 \mathrm{a}$ & $1.01 \mathrm{a}$ & $36.1 \mathrm{ab}$ & $48.6 \mathrm{ab}$ \\
\hline Mushroom media compost & $1.09 \mathrm{a}$ & $1.02 \mathrm{a}$ & $38.3 b$ & $54.7 \mathrm{~b}$ \\
\hline Oil cake & $1.10 \mathrm{ab}$ & $1.03 \mathrm{a}$ & $36.9 \mathrm{ab}$ & $50.7 \mathrm{ab}$ \\
\hline
\end{tabular}

\footnotetext{
${ }^{\dagger}$ Treatments with same letter in each column are not significantly different at the 0.05 probability level.
} 
to greenhouse soils can enhance soil aggregation formation and structure stability, resulting in decreased bulk density and increased porosity. The improved soil physical properties may supply better condition for plant root elongation and respiration by proper aeration in soil and drainage of excess water (Arshad et al., 1996). Mushroom media compost and rice straw compost significantly improve soil aggregate stability. Kim et al. (2004) reported that soil aggregate stability increment of organic amendments was in the order of hairy vetch $>$ rice straw $>$ pig manure $>$ compost, green manure, oil cake, and concluded that coarse organic materials have the advantage of an increase in water stable aggregate as compared with well-decomposed organic materials. Therefore, the results obtained from the study indicated that rice bran compost and oil cake are proper organic resources in order to increase soil organic matter, while mushroom media compost and rice straw compost to improve soil aggregate stability.

\section{Conclusion}

Application of organic amendments including oil cake, rice straw compost, amino acid compost, rice bran compost, and mushroom media (spent substrate) compost resulted in comparable growth and yield of red pepper compared with those for chemical fertilizer. In addition, soil $\mathrm{pH}$, soil organic matter, bulk density, and aggregate stability were improved by applying of the organic materials, especially rice bran compost and oil cake for soil organic matter enhancement and mushroom media compost for aggregate stability improvement. On the other hand, nutrient imbalance by phosphate accumulation and potassium deficit needs to be carefully considered when organic amendments such as rice bran compost and mushroom media compost were continuously applied to agricultural land.

\section{References}

Arshad, M.A., B. Lowery, and B. Grossman. 1996. Physical tests for monitoring soil quality. p. 123-141. In Doran, J.W. and A.J. Jones (ed.). Methods for assessing soil quality. Soil Science Society of America, Inc. Madison, WI, USA.

Buckerfield, J.C. and K.A. Webster. 2002. Organic matter management in vineyards: Mulches for soil maintenance. The Australian and New Zealand Grape-grower and Wine-maker. 461:26-30.

Cho, H-J., S-U. Hwang, K-H. Han, H-R. Cho, J-H. Shin, and L-Y. Kim. 2009. Physicochemical properties of upland soils under organic farming. Korean J. Soil Sci. Fert. 42:98-102.

Kim, L-Y., H-J. Cho, B-K. Hyun, and W-P. Park. 2001. Effects of physical improvement practices at plastic film house soil. Korean J. Soil Sci. Fert. 34:92-97.

Kim, L-Y., H-J. Cho, and K-W. Han. 2004. Changes of physical properties of soils by organic material application in farm land. Korean J. Soil Sci. Fert. 37:304-314.

Lee, Y-H., S-G. Lee, S-H. Kim, J-H. Shin, D-H. Choi, Y-J. Lee, and H-M. Kim. 2006. Investigation of the utilization of organic materials and the chemical properties of soil in the organic farms in Korea. Korean J. Organic Agric. 14:55-67.

National Agricultural Products Quality Management Service. 2012. Certified Agricultural Products Statistics, http://www. enviagro.go.kr/portal/info/Info_statistic_cond.jsp.

National Institute of Agricultural Science and Technology (NIAST). 2000. Methods of soil and plant analysis. NIAST, Rural Development Administration, Suwon, Korea.

Reddy, D.D., A.S. Rao, and P.N. Takkar. 1999. Effects of repeated manure and fertilizer phosphorus additions on soil phosphorus dynamics under a soybean-wheat rotation. Biol. Fert. Soils 28:150-155.

Seo, Y-H., J-K. Choi, S-K. Kim, H-K. Min, and Y-S. Jung. 2007a. Prioritizing environmental risks of veterinary antibiotics based on the use and the potential to reach environment. Korean J. Soil Sci. Fert. 40:43-50.

Seo, Y-H., S-J. Lim, S-K. Kim, and Y-S. Jung. 2007b. Effect of rice straw and woodchip application on greenhouse soil properties and vegetable crops productivity. Korean J. Soil Sci. Fert. 40:4-11.

Sohn, S-M. and D-H. Han. 2000. Assessment of environmentally sound function on the increasing of soil fertility by Korean organic farming. Korean J. Soil Sci. Fert. 33:193-204.

Sohn, S-M., D-H. Han, and Y-H. Kim. 1996. Chemical characteristics of soils cultivated by the conventional farming, greenhouse cultivation and organic farming and accumulation of $\mathrm{NO}_{3}{ }^{-}$in Chinese cabbage and lettuce. Korean J. Organic Agric. 5: 149-165. 